\title{
インターレース糸の摩擦交絡強度
}

\author{
葛 明橋, 家元 良幸, 田上 秀一

\section{Frictional Tangling Strength of Interlaced Yarns}

\author{
Mingquao Ge, Yoshiyuki Iemoto and Shuichi Tanoue
}

\begin{abstract}
In order to make the frictional tangling strength of interlaced yarns clear, interlaced yarns were subjected to iterative frictional forces by reciprocating rubbers and afterward their number of tangles was measured. The frictional tangling strength is defined as the ratio of the residual and original numbers of tangles. The number of friction, friction angle, static tension, friction speed and kind of yarns were used as experimental parameters. Results obtained are as follows.

(1) When the number of friction, friction angle, static tension and friction speed are large, tangling parts easily disappear. When the friction angle is large, difference in length between filaments on inner and outer sides of bending yarn is notable and occurrence of slip of filaments is easy and hence, tangling parts easily disappear owing to large bending angle of yarn and frictional force. When the static stress is large, the frictional force increases and hence, the above mentioned difference in filament length is large and the slip easily occurs. The friction speed has no effect on the frictional force. However, when the friction speed is large, every filament does not move and deform together with each other synchronously with the time variation of the frictional force and hence, the slip easily occurs.
\end{abstract}

(2) Yarns with more filaments or larger fineness show larger frictional tangling strength because of larger degree of entanglement and cohesion of filaments.

(Received 10, July, 1996)

(Accepted for Publication 14, Feb. 1997)

\section{1. 緒 言}

インターレース糸は, 繊維が互いに絡まった交絡 部と絡まっていない開繊部を糸軸方向に交互に持っ ので，集束性を有し，加工中に糸切れを起こしにく い. 単位長さ当たりの交絡部の数（交絡数）は，集 束性を左右するので，インターレース糸の基本評価 量であり，この外観に関する量の測定法がこれまで 数多く提案されてきた ${ }^{1244}$.

大きな集束性により加工性は向上するが，交絡部 が編織布に残留すると風合いや外観上の欠点となる ので, インターレース糸の交絡部は, 加工の際に受 ける引張や摩擦などの外力により, 製布工程完了時 において完全に消滅することが望まれる，従って， インターレース加工では, 加工直後の交絡数だけで
なく，外力を受けた後の交絡の残留の度合いを把握 することが必要である. 外力を受けた後の交絡部の 残留度合いを交絡強度と呼ぶ. 交絡強度は, 外観か ら評価できないが，インターレース糸に内在する重 要な評価量であり，インターレース系には適切な交 絡強度を有することが望まれる。

交絡強度に関する主な測定方法には以下のものが ある.

(1) 糸に一定張力を一定時間与えた後, 張力を除 き, 残留した交絡数と元の交絡数の比で評価す $3^{25,26)}$.

（2) 応力緩和実験を利用する方法で，糸に一定伸 長歪を一定時間与えた後の張力により評価する. 交 絡強度が大きければ, 伸長後の糸は伸長前の糸の形 態を保持するので, 張力は大きい, 逆に交絡強度が

会員, Member, 福井大学工学部, 福井市文京 3-9-1, Faculty of Engineering, Fukui University, 3-9-1, Bunkyo, Fukui. 
小さければ，交絡部が消滅して糸は長くなり，張力 は小さい。この方法は, タスラン糸の評価に用いら れた27).

(3) 疲労実験を利用する方法で，一定回数繰り返 し応力を与えた後, 残留した交絡数と元の交絡数の 比により評価する。

(4) 一定速度で走行する系に摩擦体により摩擦力 を付与した後, 系の見かけの外径を光量あるいは静 電容量の変化によりオンライン計測し，元の系の見 かけの外径と比較して評価する ${ }^{28)}$.

(5) 一定速度で走行する糸をその糸自身により摩 擦した後, 残留した交絡数と元の交絡数の比により 評価する ${ }^{29}$.

このように, 交絡強度は外力を与えた後の交絡数 を測定することだけでなく，張力によっても評価さ れる，交絡強度を評価するために加えられる外力 は, (1), (2)では静的な引張力, (3)では繰り返し引張 力, (4), (5)では静的な引張力に組み合わされた一定 摩擦力であり, (1), (2)では静的引張交絡強度, (3)で は繰り返し引張交絡強度, (4), (5)では定常摩擦交絡 強度が測定される。

以上のように，交絡強度を評価するために様々な 種類の外力や測定対象が用いられている. しかし， 製編織時には緊張状態の糸に摩擦力が繰り返し加え られるので, 静的引張交絡強度や定常摩擦交絡強度 より屯繰り返し摩擦交絡強度の方がより実際的であ ると思われるが, 繰り返し摩擦力がインターレース 糸の交絡強度に及ぼす影響は明らかにされていな い.

そこで, 本報では, 摩擦回数, 摩擦角度, 摩擦速 度, 摩擦力, 糸番手, 繊維緘度, 繊維数などの諸因 子が, 繰り返して摩擦力を受けた緊張状態のインタ ーレース糸の交絡強度に及ぼす影響を検討した結果 について述べる，なお，交絡数は容易に測定できる 直裁的な量なので, 残留交絡数と元の交絡数の比に より交絡強度を定義する。

\section{2. 実験装置および方法}

\section{1 試料糸}

表 1 に示す 4 種類のポリエステルマルチフィラメ ント仮撚加工糸を, 基本形状のインターレーサ ${ }^{8}$ (糸 道管直径 $2.8 \mathrm{~mm}$, 系道管長さ $14.7 \mathrm{~mm}$, 空気噴射 ズル直径 $1.4 \mathrm{~mm}$ ，ガイド間距離 $31.5 \mathrm{~mm}$ ）を用い て, 糸速度 $200 \mathrm{~m} / \mathrm{min}$, フィード率 $1 \%$, 作動空気圧
Table 1 Interlaced yarns

\begin{tabular}{l|c|c|c|c}
\hline \hline notation & $\mathrm{Y}_{1}$ & $\mathrm{Y}_{2}$ & $\mathrm{Y}_{3}$ & $\mathrm{Y}_{4}$ \\
\hline yarn count [d] & 152 & 152 & 99 & 76 \\
\hline number of filaments & 48 & 34 & 34 & 24 \\
\hline fineness [d] & 3.17 & 4.47 & 2.91 & 3.17 \\
\hline number of tangles [m $\left.{ }^{-1}\right]$ & 103 & 101 & 108 & 106 \\
\hline
\end{tabular}

$0.3 \mathrm{MPa}$, 初期張力 $0.5 \mathrm{mN} / \mathrm{d}(1 \mathrm{mN}=0.102 \mathrm{gf})$ の条 件下でインターレース加工し, 試料系とした。系 $Y_{1}$ と $\mathrm{Y}_{2}$ は，番手が同じで，繊維数と繊維繊度が異な る. $\mathrm{Y}_{1}$ と $\mathrm{Y}_{4}$ は, 絾維繊度が同じで, 番手と繊維数 が異なる， $\mathrm{Y}_{2}$ と $\mathrm{Y}_{3}$ は, 繊維数が同じで, 番手と繊 維繊度が異なる。このように番手, 繊維数, 緘維䋐 度の異なる糸を用いて, 糸種類か摩擦交絡強度に及 ぼす影響を調べた．表中に示す各糸の交絡数は，張 力 $0.3 \mathrm{mN} / \mathrm{d}$ を加えたときの糸長 $5 \mathrm{~m}$ をマークし， 張力を取り除いた後に目視により測定したもので, その值は互いにほぼ等しい。

\section{2 実験装置および装置特性}

図 1 に実験装置を示す．系の一端を張力計に固定 し，他端に重りを吊す。この重りにより，系に静的 張力 $\sigma_{s}$ を与える. 糸に摩擦力を付与する摩擦子は, 上部 3 枚, 下部 2 枚のクロムメッキを施したマンガ ン鋼板（厚さは $0.4 \mathrm{~mm}$, 系との接触部は半径 0.2 $\mathrm{mm}$ の円弧，表面粗さ $R_{a}=0.14 \mu \mathrm{m} ）$ で構成されて いる． 5 枚のマンガン鋼板は一体に組み立てられて おり，各鋼板の間隔は $6 \mathrm{~mm}$ である．糸と摩擦子の 接触角度 (以後, 摩擦角度という) $\delta$ は, 上下鋼板の 距離を調整することにより変えることができる，モ 一タに接続したクランク・ピストン機構（クランク 長さ $R=45 \mathrm{~mm}$, 連結棒長さ $L=160 \mathrm{~mm} ）$ によ， 摩擦子は水平方向に行程 $90 \mathrm{~mm}$ の往復運動をする. 摩擦子のクランク軸からの距離を $s$, 時間を $t$, クラ ンクの回転角速度を $\omega$ とすると, 摩擦子の変位方程 式は

$$
s(t)=R \cos \omega t+\sqrt{L^{2}-(R \sin \omega t)^{2}}
$$

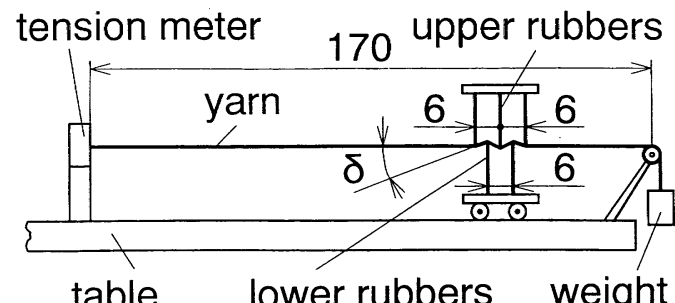

Fig. 1 Experimental apparatus 


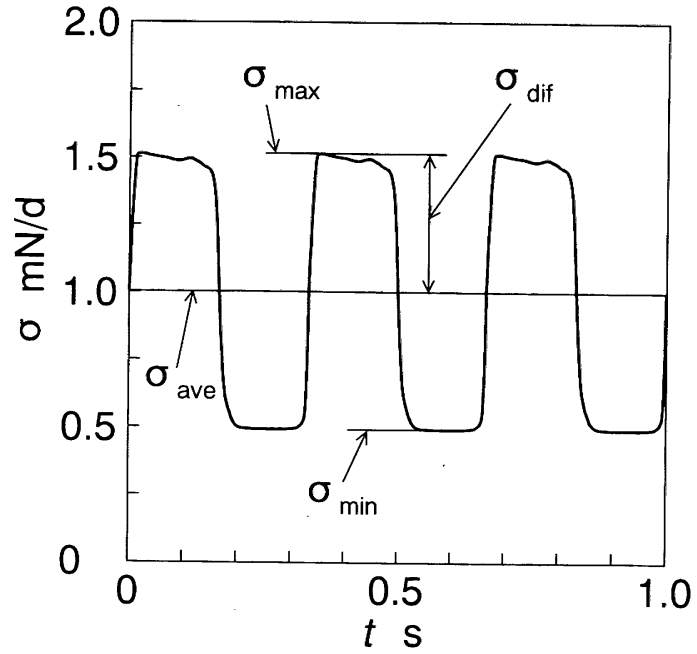

Fig. 2 Time variation of yarn tension $\left(\mathrm{Y}_{1}: 152 \mathrm{~d} / 48\right.$ f, $\left.\delta=15^{\circ}, \sigma_{s}=1 \mathrm{mN} / \mathrm{d}, n_{c}=180 \mathrm{rpm}\right)$

により表される.

次に, 本実験装置の特性について調べた. 図 2 に, 摩擦角度 $\delta=15^{\circ}$, 静的張力 $\sigma_{s}=1 \mathrm{mN} / \mathrm{d}$, クランク の回転速度 (以後, 摩擦速度という) $n_{c}=180 \mathrm{rpm} に$ おける糸 $Y_{1}$ の張力 $\sigma$ を示す. 図より, 糸張力 $\sigma$ は 時間 $t$ ととあに周期的に変化する動的張力である. 動的張力の特性値として, 図に示した最大張力 $\sigma_{\max }$, 最小張力 $\sigma_{\min }$, 張力差 $\sigma_{\mathrm{dif}}=\left(\sigma_{\max }-\sigma_{\min }\right) / 2$, 平均 張力 $\sigma_{\mathrm{ave}}=\left(\sigma_{\max }+\sigma_{\min }\right) / 2$ を定義する.

図 3 は, 糸 $Y_{1}$ の動的張力の特性値に対する各種

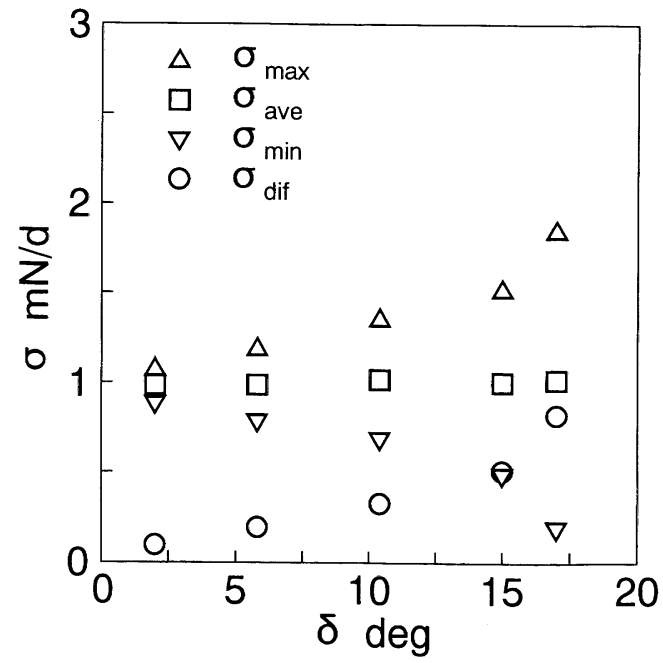

(a) Effect of friction angle $\left(\sigma_{\mathrm{s}}=1 \mathrm{mN} / \mathrm{d}, n_{\mathrm{c}}=\right.$ 180rpm)
測定パラメータの影響を示したものである. 図(a)に は, $\sigma_{s}=1 \mathrm{mN} / \mathrm{d}, \quad n_{c}=180 \mathrm{rpm}$ において $\delta$ が動的張 力の特性值に及ぼす影響を示す。図より， $\sigma_{\text {ave }}$ は $\sigma_{s}$ とほぼ等しく $\delta$ の影響は見られないが, 糸に付与さ れる摩擦力 $\sigma_{\text {dif }}$ は, 摩擦子の運動方向にかかわらず 一定で, $\delta$ の増加ととあに急激に増加する. 図 (b) に, $\delta=15^{\circ}, n_{c}=180 \mathrm{rpm}$ において $\sigma_{s}$ が動的張力の 特性値に及ぼす影響を示す. 動的張力の各特性值は $\sigma_{s}$ に対してほぼ正比例で増加する. 図 (c)に, $\delta=$ $15^{\circ}, \sigma_{s}=1 \mathrm{mN} / \mathrm{d}$ において $n_{c}$ が動的張力の特性值に 及ぼす影響を示す. 動的張力の特性値は $n_{c}$ に関係

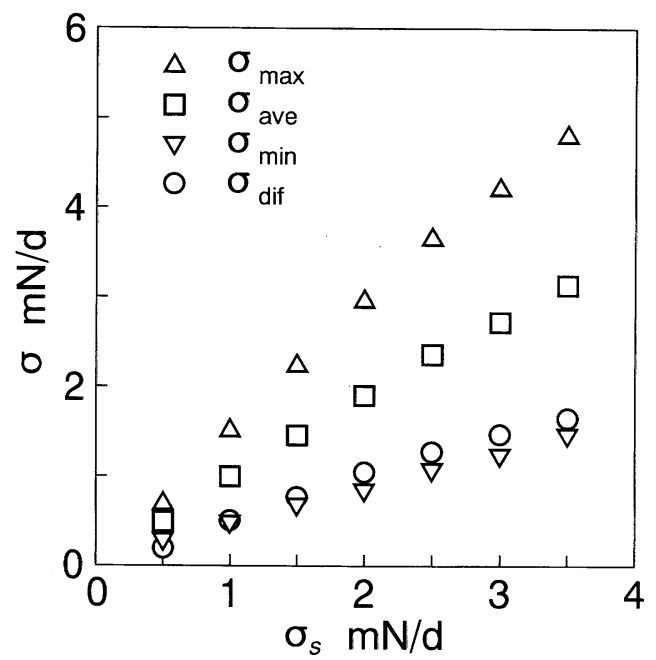

(b) Effect of static tension $\left(\delta=15^{\circ}, n_{c}=180\right.$ rpm)

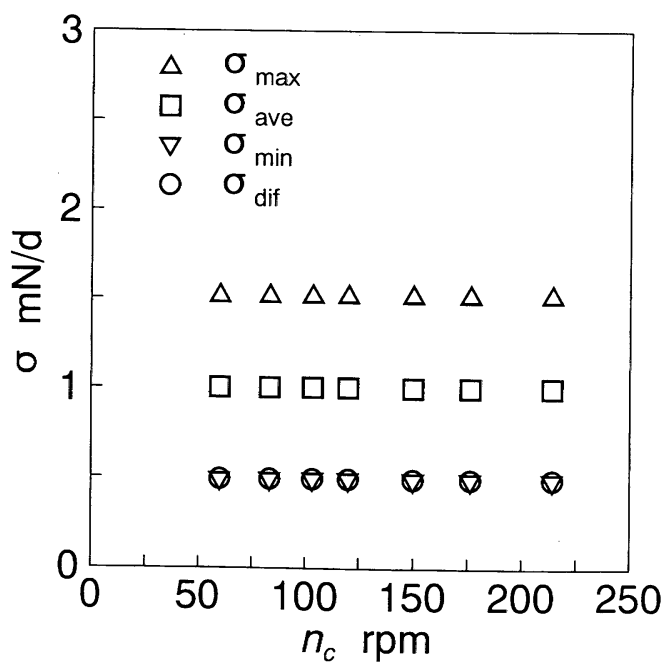

(c) Effect of friction speed $\left(\delta=15^{\circ}, \quad \sigma_{s}=1\right.$ $\mathrm{mN} / \mathrm{d}$ )

Fig. 3 Yarn tension $\left(Y_{1}: 152 d / 48 f\right)$ 


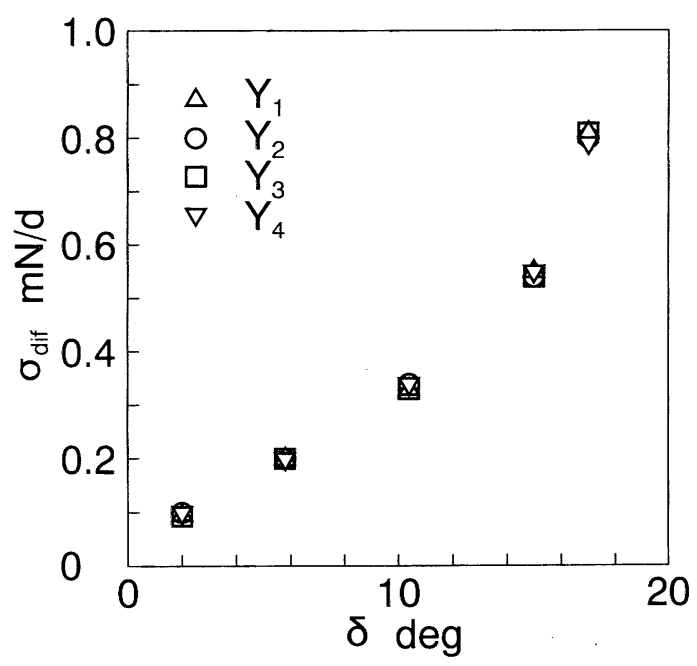

Fig. 4 Frictional force $\left(\sigma_{s}=1 \mathrm{mN} / \mathrm{d}, n_{c}=180 \mathrm{rpm}\right)$

なく，それぞれ一定値となる.

図 4 に, 系 $\mathrm{Y}_{1} \sim \mathrm{Y}_{4}$ に生じた摩擦力 $\sigma_{\mathrm{dif}}$ を示す. 実 験条件は, $\sigma_{\mathrm{s}}=1 \mathrm{mN} / \mathrm{d}, n_{c}=180 \mathrm{rpm}$ である。 $\sigma_{\text {dif }}$ は, 系種に依存しないことがわかる. なお, 図示を省く が，いずれの糸の動的張力む $n_{c}$ に依存しないこと は確認済みである。

\section{3 実験方法}

前節2.2で述べた特性を持つ糸摩擦実験装置を用 いて, 試料糸の表面を摩擦子で繰り返し摩擦し, 残 留交絡数を次のようにして測定した．摩擦子の運動 距離は $90 \mathrm{~mm}$ なので, 摩擦子の長さ $12 \mathrm{~mm}$ を差し引 いた糸の中央部执よそ $50 \mathrm{~mm}$ に位置する交絡部に 注目し, 摩擦力を加える前の交絡部が摩擦力を加え た後に残留するか否かを, 無張力状態で目視により 判定した．系の中央部を測定対象とすることによ り, 注目する交絡部の全域を摩擦するという条件を 満足するとともに, 摩擦子の運動に依存して糸の伸 びが変化するために糸の摩擦箇所が移動する ${ }^{30)}$ とい う問題を解決した. 張力 $0.3 \mathrm{mN} / \mathrm{d}$ を加えたときの 糸長 $5 \mathrm{~m}$ に存在する交絡部を測定対象とするため に, 1 つの実験条件について測定を 100 回繰り返し, 残留交絡数を求めた.

本研究で議論の対象とする摩擦交絡強度 $S_{t}$ を, 残留交絡数 $N_{r}$ と表 1 に示した摩擦力を加える前の 交絡数 $N$ を用いて,

$$
S_{t}=N_{r} / N
$$

により定義した.

\section{3. 結果および考察}

\section{1 摩擦回数の摩擦交絡強度に対する影響}

図 $5\left(\right.$ a)に, 摩擦回数 $n_{f}$ が摩擦交絡強度 $S_{t}$ に及ほ す影響を 4 種類の試料糸について示す．ただし，摩 擦回数 1 回はクランク軸 1 回転と定義する. 実験条 件は, 摩擦角度 $\delta=15^{\circ}$, 静的張力 $\sigma_{s}=1 \mathrm{mN} / \mathrm{d}$, 摩擦 速度 $n_{c}=180 \mathrm{rpm}$ である. 図より, 摩擦開始の領域 $\left(n_{f} \leqq 50\right)$ において, 摩擦交絡強度は急激に減少して いる.これは，1本のインターレース糸の中に交絡 強度の強い交絡部之弱い交絡部があり, 弱い交絡部 は摩擦力を受けると直ちに解体するためである. 弱 い交絡部の数はいくら多くてあ, 系の使用に対して 役立たない，糸の使用に対して役立つのは残留した 強い交絡部だけである. 従って, 弱い交絡部の数と 強い交絡部の数の比率も, インターレース糸, イン ターレーサおよびインターレース加工条件の評価量 の 1 つと考えることができる.

$n_{f}$ をさらに増加すると， $S_{t}$ はほぼ直線的に減少 し， $n_{f}$ は交絡部の解体に対して大きく影響すること がわかる．作用する方向の変化する摩擦力は, 系を 伸ばしたり, 弛ませたりするので, 静的引張力に比 べ, 容易に繊維同士の絡みを解体させることができ る.

\section{2 摩擦角度の摩擦交絡強度に対する影響}

図 5 (b)に，摩擦角度 $\delta$ が $S_{t}$ に及ぼす影響を示す。 実験条件は， $n_{f}=100, \sigma_{s}=1 \mathrm{mN} / \mathrm{d}, n_{c}=180 \mathrm{rpm}$ で ある. 横軸の值が 0 におけるプロットは, $S_{t}=1$ であ り，系に摩擦力を与える前の値を示している（以下 の図も同じ). 図より， $S_{t}$ は $\delta$ の増加とともに減少 する. 繊維が摩擦子により急な角度で曲げられる と, 曲げられた部分の外側の繊維は引っ張られて長 く, 内側の繊維は圧縮されて短くなるため, 外側と 内側で繊維長さの差が顕著になる.このため, 繊維 間ですべりが起こりやすく, 交絡部が解体されやす い.これに加えて, 図 $3(\mathrm{a}) に よ り ， \delta$ の増加ととも に, $\sigma_{\max }$ は増加し, $\sigma_{\min }$ は隇少して, 摩擦力 $\sigma_{\mathrm{dif}}$ は増 加するために, 曲がり部分の内外における繊維長さ の差が大きくなり, 交絡部は解体されやすくなると 考えられる.

\section{3 糸張力の摩擦交絡強度に対する影響}

図 5 (c)に, 静的張力 $\sigma_{s}$ が $S_{t}$ に及ぼす影響を示す. 


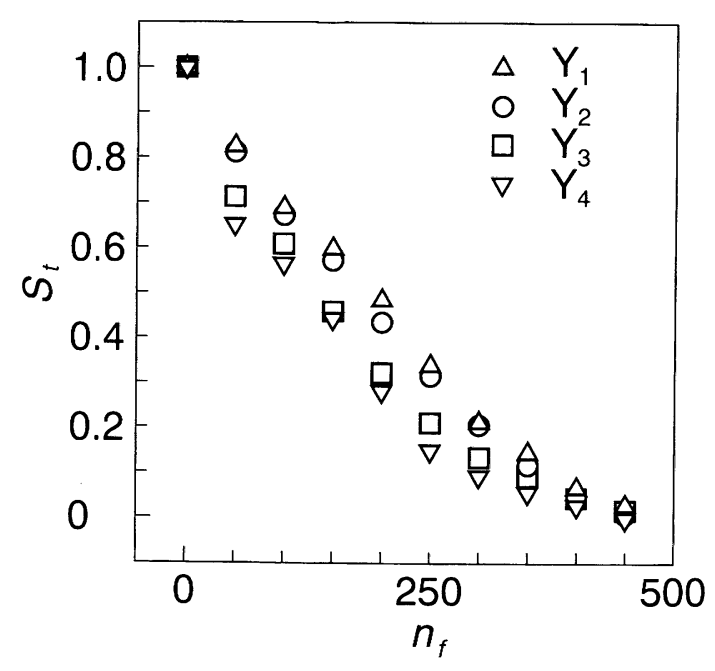

(a) Effect of number of frictions

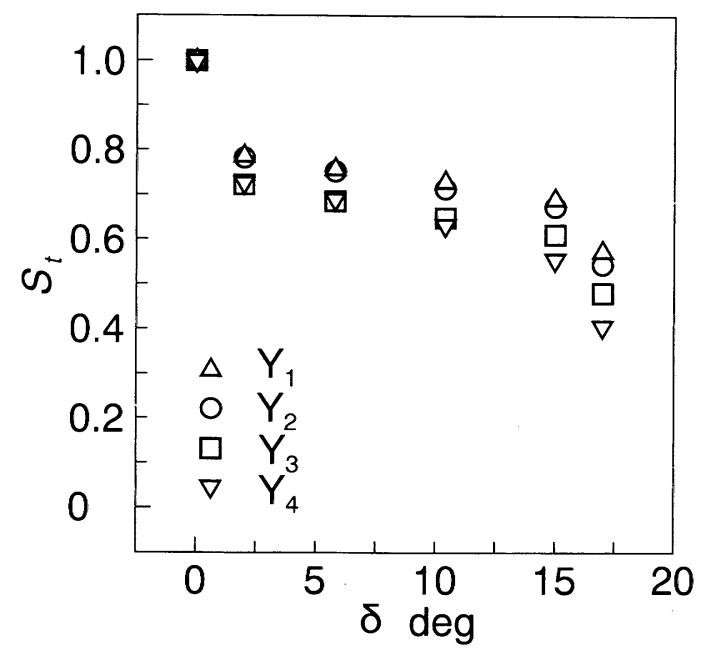

(c) Effect of friction angle

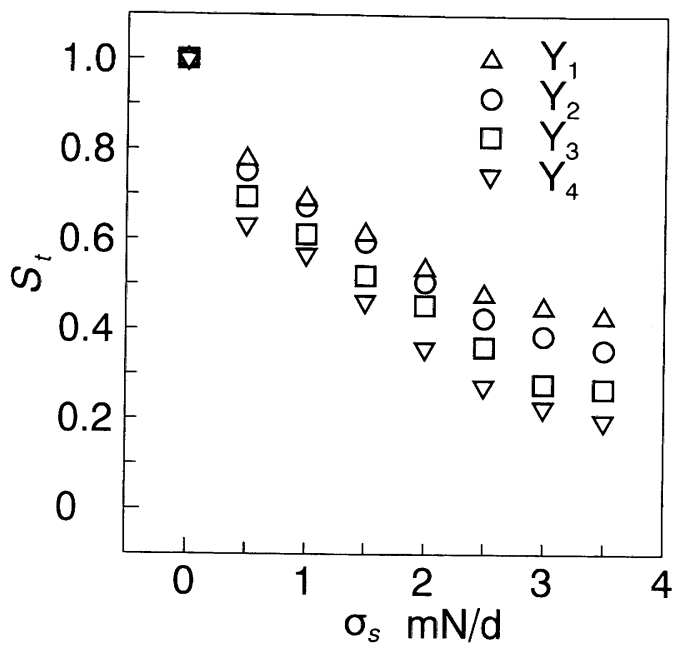

(b) Effect of static tension

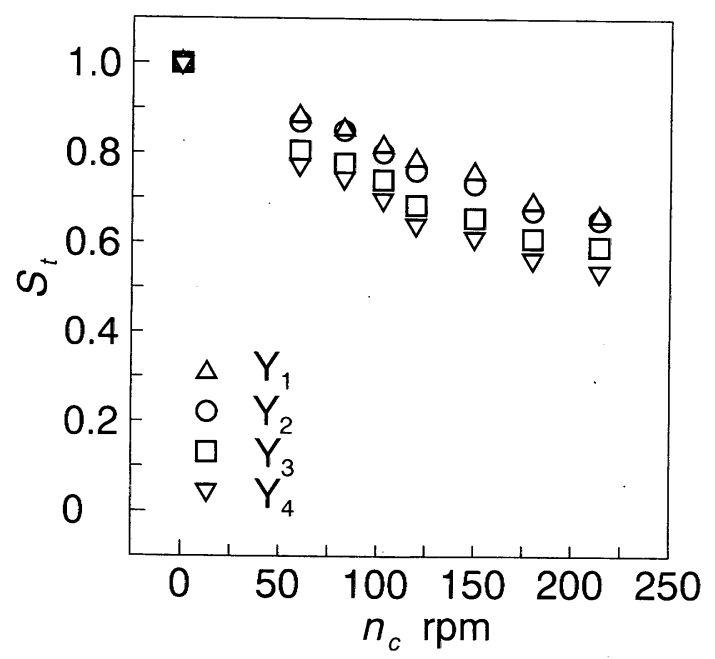

(d) Effect of friction speed

Fig. 5 Tangling strength

実験条件は, $n_{f}=100, \delta=15^{\circ}, n_{c}=180 \mathrm{rpm}$ である. 図より， $S_{t}$ は $\sigma_{s}$ の増加とともに減少していること がわかる。

交絡部はインターレーサ内における空気力の作用 で織維の互いの位置が入れ替わることにより形成さ れている. フラット糸の場合, 非交絡部の繊維同士 は互いに平行であり, 交絡部では屈曲した繊維同士 が互いに絡まり, 繊維間の摩擦により交絡部を保持 している ${ }^{31)}$ ，逆に交絡部が解体するためには，屈曲 して絡んだ緎維が緎維間の摩擦力を克服して, 真っ 直ぐな姿勢をとる必要がある. 糸が摩擦子から摩擦 力を受けて引き伸ばされたときに, 屈曲して絡んだ
繊維が真っ直ぐに伸ばされようとする一方で, 䋐維 間の摩擦力屯系張力とともに増加し, 絡んだ繊維が 真っ直ぐになることを妨げる. 従って, 交絡部は図 示した程度の大きさの $\sigma_{s}$ で解体しない.

従って, 交絡部の解体は, 図 $3(\mathrm{~b})$ に示したように $\sigma_{s}$ の増加とともに摩擦力 $\sigma_{\mathrm{dif}}$ が増加したために生じ たと考えられ, 動的張力 $\sigma$ は交絡部の解体に対して 大きな影響を持つことがわかる.

\section{4 摩擦速度の摩擦交絡強度に対する影響}

図 5 (d)に，摩擦速度 $n_{c}$ が $S_{t}$ に及ぼす影響を示す。 実験条件は, $n_{f}=100, \delta=15^{\circ}, \sigma_{s}=1 \mathrm{mN} / \mathrm{d}$ である. 
図 3 (c)に示したように, $n_{c}$ が増加しても動的張力の 特性值は変わらないが, 図 $5(\mathrm{~d})$ より, $S_{t}$ は $n_{c}$ の増加 とともに減少し, 摩擦速度は交絡部の解体に対して 大きい影響があることがわかる。

摩擦速度が小さい場合には, 摩擦子により糸に付 与された張力と糸の曲がりの向きが緩慢に変化し, 繊維の振動が小さくなる。このため, 繊維間の摩擦 力も系に付与された張力の変化に同調して変わり, 絡んだ䋐維同士の相対的な移動が難しくなり, 交絡 部は解体し難くなる，逆に，摩擦速度が大きい場合 には, 摩擦子により糸に付与された張力と糸の曲が りの向きが急速に変化し, 系は急速な引っ張りと弛 みの作用を繰り返して与えられ, 絡んだ繊維が振動 しやすくなる．このため, 繊維間の摩擦力の変化は 糸張力の変化に同調せず, 絡んだ繊維は互いに滑り やすくなり，交絡部は解体しやすくなる.

\section{5 糸種類の摩擦交絡強度に対する影響}

図 5 に示した測定結果を用いて，糸種類の摩擦交 絡強度に対する影響について考察する. 摩擦パラメ 一夕 $\delta, \sigma_{s}, n_{c}$ を変化させてあ, 糸 $\mathrm{Y}_{1} \sim \mathrm{Y}_{4}$ に生じる 動的応力の特性値は糸種類によって変化しない。し かしながら, 図 5 より, 摩擦パラメー夕 $n_{f}, \delta, \sigma_{s}$, $n_{c}$ の増加に伴う $S_{t}$ の減少の程度は系により異なる。

まず，糸 $Y_{1}(152 d / 48 f)$ と糸 $Y_{2}(152 d / 34 f)$ につ いて比べる，共通点は番手であり，相違点は繊維㵶 度と繊維数である. 図より, 番手が同じ場合には, 繊維繊度が小さく繊維数が多い糸の摩擦交絡強度が 強いことがわかる。これは，緘維繊度が小さく繊維 数が多い系の方が, 緎維同士の絡みが多い上に, 緎 維同士の接触面積が大きいので, 交絡部で繊維間の 摩擦力が大きく, 抱合力が大きいためである.

次に, 系 $Y_{1}(152 d / 48 f)$ と系 $Y_{4}(76 d / 24 f)$ につ いて比較する，共通点は緎維繊度であり，相違点は 番手と繊維数である. 図より, 繊維繊度が同じ場合 には, 番手が大きく繊維数が多い系の摩擦交絡強度 が強いことがわかる.これは, 上述のように, 緘維 数が多い系は, 交絡部で繊維同士の絡みと抱合力が 大きいためである.

最後に, 糸 $\mathrm{Y}_{2}(152 \mathrm{~d} / 34 \mathrm{f})$ と糸 $\mathrm{Y}_{3}(99 \mathrm{~d} / 34 \mathrm{f})$ に ついて比較する，共通点は緎維数であり，相違点は 番手と繊維繊度である，図より，䋐維数が同じ場合 には，番手が大きく繊維緘度の大きい糸は摩擦交絡 強度が強いことがわかる。これは, 番手が大きく㵶 維繊度の大きい糸の方が, 交絡部で繊維同士の抱合
接触面積が大きいので, 繊維同士の摩擦力も大き く，交絡部の絡みと抱合力が大きいためである．繊 維繊度の大きい系は, 繊維の曲げこわさが大きいた めに，繊維同士は絡みにくいと考えられるが，一度 形成された交絡部の摩擦交絡強度は大きいと思われ る.

以上の検討から，本研究で用いた糸の摩擦交絡強 度は糸 $\mathrm{Y}_{1}, \mathrm{Y}_{2}, \mathrm{Y}_{3}, \mathrm{Y}_{4}$ の順に減少する。

\section{4. 結 言}

インターレース系に往復運動する摩擦子を用いて 繰り返し摩擦力を加え, 摩擦回数, 摩擦角度, 静的 張力, 摩擦速度, 糸種類をパラメータとした場合の 残留交絡数を測定することにより，インターレース 系の摩擦交絡強度について検討した.

得られた主な結果を以下に記す。

(1)摩擦回数, 摩擦角度, 静的張力, 摩擦速度が大 きいほど，交絡部は解体しやすい，摩擦角度が大き いほよ゙，糸の曲がる角度が大きくなる上に摩擦力が 大きくなるので，曲がりの内外における繊維長さの 差が著しくなり繊維間に滑りが起こりやすく, 交絡 部の解体が起こりやすい，静的張力が大きいぼど, 摩擦力も大きくなり, 曲がりの内外の繊維の長さの 差が大きくなって，繊維間の滑りが起こりやすい． 摩擦速度は摩擦力に影響しないが，この量が大きく なると, 各繊維が摩擦力の時間変化に追随して運動 ・変形せず, 纃維間に滑りが生じて, 交絡部の解体 が促進される.

(2)繊維数や繊維繊度が大きい糸ほど，䋐維同士の 絡まりと抱合力が大きいので, 摩擦交絡強度は大き い.

\section{参考文献}
1）加藤，前沢；特開昭61-119745
2) 根岸; 特開昭51-64054
3）佐野，小笠原，椿森 ; 特公昭55-30457
4）鳳, 四衛, 植木; 特開平 4-202820
5）田尻，湯上；特開平 5-33235
6) 釜本, 竹内, 阿部 ; 特開平 6-220732
7）佐野，小笠原；特開昭55-67030
8）佐野，小笠原；特開昭58-115170
9）川俣, 斉藤, 今川, 石川, 岸本 ; 特開昭57-193541
10）吉岡, 平井, 浅山; 特開昭54-66880
11）加藤, 前沢, 笠岡 ; 特開昭61-194268
12）楼，家元，蝶野; 織機誌，48，T29（1995）
13）ウオルター・クラーク・グレイ；特公昭50-28533
14）伊藤, 谷口, 生井; 特開昭54-134157
15）下村, 谷口; 特開昭56-26068 
16）松村，楠本；特開昭54-43092

17）松村, 楠本 ; 特開昭54-147255

18）下村, 谷口; 特開昭58-104266

19）渡辺，坂倉，木下；特開昭61-124671

20）佐野，椿森，小笠原；特開昭58-115139

21）白坂, 大石, 石本, 為田 ; 特開昭59-26570

22）藤浦, 東野, 白坂 ; 特開昭59-30958

23）山口 ; 特開昭61-63766

24）家元，蝶野，葛；織機誌，46，T107（1993）
25）大滝，中川；特開昭54-156843

26) 松本, 中川 ; 特開昭55-132728

27）岩田，片山，梅田；特開昭57-120860

28）真栄田，井上；特開昭64-61531

29) H. Weinsdörfer; Chemiefasern/Textilindustrie, 36/88, 289 (1986)

30）安藤，金，高橋，原川；繊機誌， 41，T125（1988）

31）家元, 蝶野, 寺地; 織機誌, 42, T114（1989） 